\title{
Catalytic Conversion of Oil and Gas Residue to Liquid Fuel Using Heterogeneous Catalysts
}

\author{
Pusparatu $^{1, *}$ R.Y. Perry Burhan ${ }^{1,2}$ Sylvia Yusnica ${ }^{1}$ Oksil Venriza $^{1}$ \\ ${ }^{1}$ Politeknik Energi dan Mineral AKAMIGAS, 58315, Indonesia \\ ${ }^{2}$ Institute Teknologi Sepuluh November, 60111, Indonesia \\ *Corresponding author.Email: pusparatu2000@yahoo.com
}

\begin{abstract}
Petroleum residue is a by-product of oil refineries that has not been utilized optimally so that it accumulates in the stockpile tank causing disruption of the processing of petroleum into motor vehicle fuel. The catalytic conversion of oil and gas residue into liquid fuel has been carried out using a heterogeneous acid catalyst using a bath reactor which has resulted in a conversion of $40 \%$ with a temperature of $350^{\circ} \mathrm{C}$ for 60 minutes with a pressure of $1 \mathrm{~atm}$. The resulting product was analysed using Gas Chromatography Mass Spectroscopy (GCMS) with components $\mathrm{C}_{1}$ to $\mathrm{C}_{17}$ hydrocarbon. The effect of temperature on the catalytic cracking of petroleum residue has also been studied with the result that increase in temperature will increase the catalytic conversion of crude oil residue.
\end{abstract}

Keywords: Catalytic, Residue, Heterogeneous, Fuel.

\section{INTRODUCTION}

Petroleum residue is the lowest fraction in the processing of petroleum with the highest boiling point. Therefore, at room temperature $\left(20-30^{\circ} \mathrm{C}\right)$ the residue is generally in solid form. In the problem, the residue always accumulates in the storage tank, this is due to the very cheap selling price so that crude oil processing will be disrupted by the full storage tank, in addition to the results of processing crude oil into fractions with very low quality so that it does not meet as motorized fuel. However, it is only used as a solvent of poor quality. Another thing if processing the residue requires a complex and expensive reactor unit, alumina, silica, zeolite catalysts are used or a mixture of alumina and silica which is acidic, where using a catalyst does not get the desired product selectivity, such as a good quality gasoline fraction.

The residue of the PPSDM Migas refinery processing has not been utilized optimally so that the residue from the processing results has accumulated in the tank. So that the residue of the PPSDM Migas refinery can be utilized or can be sold at a high price, further processing is necessary. Residue processing can be carried out in several ways, including a blending process with additive components that reduce the pour point so that it can be sold as ship fuel (MFO) and the residual catalytic hydroconversion to Crude Oil [1], or a reprocessing process using catalysts such as: Heavy reaction catalytic processing with Zeolite ZSM-5 [2-4], catalytic craking residues with Zirconia- Supporting Iron Oxide [5] and Fluid Catalytic Cracking [6]. RFCC nano zeolite-based catalyst preparation and evaluation of the Catalytic Performance Process at the RFCC [7], Zeolite HZSM-5 as an additive for catalytic cracking residue [8-12]

In addition, Indonesia is experiencing a fuel oil (BBM) crisis which can be predicted by three data, namely: (1) Indonesia's oil production has continued to decline after reaching its peak in the 1980s; of nearly 1.6 million barrels/day, currently only 1.2 million barrels / day (2) Growth in domestic energy consumption which reached $10 \%$ per year, and (3) The trend of world oil prices that continued to increase after the monetary crisis that hit Asia in 1998 [13]. To avoid the oil energy crisis in the future, efforts to meet energy needs must be focused on finding and utilizing alternative energy sources of oil that are efficient, economical and environmentally friendly, thereby reducing the role of petroleum, by creating clean technology and efforts to protect the global environment. One of the steps that can be taken is to improve the quality (upgrading) of the residue from petroleum fractionation. In general, the purpose of the up-grading process of petroleum residues is to convert large molecular weight hydrocarbons into smaller molecular weight oils (cracking) which have small molecular weights, with boiling points below 
$525^{\circ} \mathrm{C}$. This conversion requires breaking the carboncarbon and carbon-sulphur bonds and increasing the $\mathrm{H} / \mathrm{C}$ atomic ratio in the product, making it suitable for transportation fuels such as diesel or gasoline. This research is focused on finding a catalyst and operating conditions for the processing of PPSDM Migas residue into Light Naphtha. So, in this paper we present a solid acid catalyst with $0,5 \times 0,5 \mu \mathrm{m}$ with various catalyst pores so that it is expected to get gasoline fractions with high octane numbers.

\section{METHOD}

Synthesis of ZSM-5 by DGC method [14]. A typical procedure $\left(100 \mathrm{mmol}\right.$ of $\left.\mathrm{SiO}_{2}\right)$ was as follows: $100 \mathrm{SiO}_{2}: 1 \mathrm{Al}_{2} \mathrm{O}_{3}: 58 \mathrm{TPAOH}: 15 \mathrm{NaOH}: 3000 \mathrm{H}_{2} \mathrm{O}$. The The initial solution was stirred to give a homogeneous gel. Despite the hydrothermal method, here, the initial gel was dried at $80^{\circ} \mathrm{C}$ temperatures. The resultant dried gel was put into an autoclave with a small amount of distilled water. This cup was placed in a Teflon-lined autoclave $(125 \mathrm{ml})$ with the support of a Teflon holder. Small amounts of external bulk water ( $c a .0 .2 \mathrm{~g}$ per $1 \mathrm{~g}$ of dry gel), was placed at the bottom of the autoclave. The crystallization was carried out at $175^{\circ} \mathrm{C}$ for $30 \mathrm{~h}$. After the crystallization was completed, the autoclave was cooled to room temperature. The zeolite was removed from the cup, washed thoroughly with distillate water and dried at room temperature over night. To remove the organic SDA occluded inside the pores, the assynthesized zeolite sample was kept in a muffle furnace, and heated in a flow of air $(50 \mathrm{ml} / \mathrm{min})$. The temperature was increased from room temperature to $550^{\circ} \mathrm{C}$ for $4 \mathrm{~h}$ $\left(2^{\circ} \mathrm{C} / \mathrm{min}\right)$, and maintained at this temperature for $7 \mathrm{~h}$. Finally the sample was cooled to room temperature under ambient conditions. Ion Exchange is carried out to replace the neutral sodium atom with a hydrogen atom which will make the catalyst an acid catalyst.

Residue cracking catalytic is carried out to change the residue into smaller components (light naphtha) at a temperature of $300-450^{\circ} \mathrm{C}$ with a pressure of $1 \mathrm{~atm}$ in a batch reactor. The residual cracking catalytic test was carried out at PEM Akamigas using the batch type 100 $\mathrm{ml}$ batch reactor facility.

\section{RESULT AND DISCUSSION}

SEM observations on the PR-02-2020 sample showed more varied grain characteristics, with a grain size range of $5 \mu \mathrm{m}$ to $200 \mu \mathrm{m}$ or equivalent to the size of silt to fine sand. Morphologically, the grain shape in the PR-022020 sample is spherical with a rounded surface to some which is slightly tapered, and at some points the spherical grains are found to coalesce to form lumps or coagulation. The level of uniformity of the size of the sample compiler grains is classified as poor to moderate (See Figure 1). The SEM appearance generally shows grains with a grain size range of $5-200 \mu \mathrm{m}$, which is equivalent to the size of silt to fine sand. Morphologically, all the constituent grains in the sample show a generally rounded surface area, but some grains have a slightly tapered part, and poor to moderate uniformity. The main compositions that make up the granules in this sample are Silica $\left(\mathrm{SiO}_{2}\right)$ and Alumina $\left(\mathrm{Al}_{2} \mathrm{O}_{3}\right)$. The SEM detail image shows the results of SEM-EDX observations on several representative grains, with the general chemical composition dominated by Silica $\left(\mathrm{SiO}_{2}\right)$ with a mass percentage (mass\%) between $39.32 \%-67.25 \%$ and Alumina $\left(\mathrm{Al}_{2} \mathrm{O}_{3}\right)$ between $32.75 \%$ $-60.68 \%$.

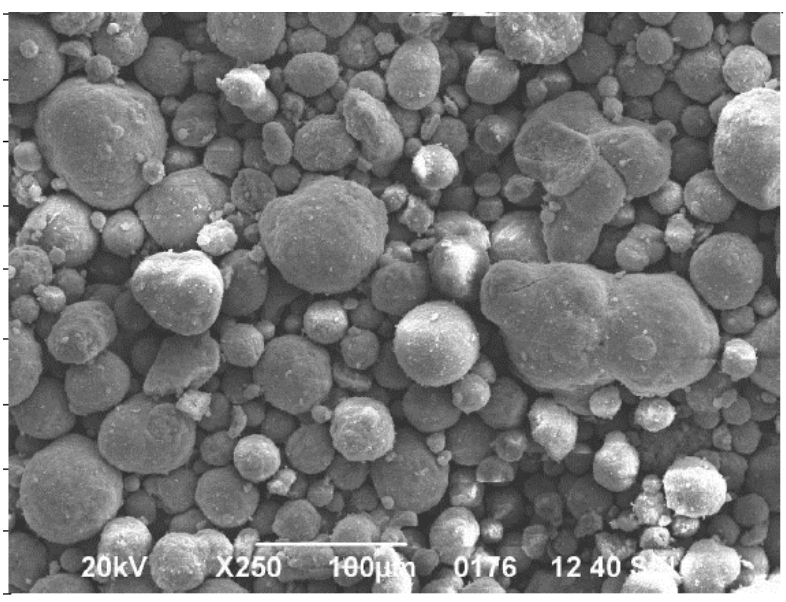

Figure 1 SEM of catalyst

EDX analysis of the constituent components of the sample shows that all the granules have componentforming compounds with relatively the same composition, namely composed by Silica $\left(\mathrm{SiO}_{2}\right)$ and Alumina $\left(\mathrm{Al}_{2} \mathrm{O}_{3}\right)$ with the percentage of mass (mass\%) Silica ranging from $39.32 \%-67.25 \%$ and Alumina $\left(\mathrm{Al}_{2} \mathrm{O}_{3}\right)$ between $32.75 \%-60.68 \%$ (Figure 2).

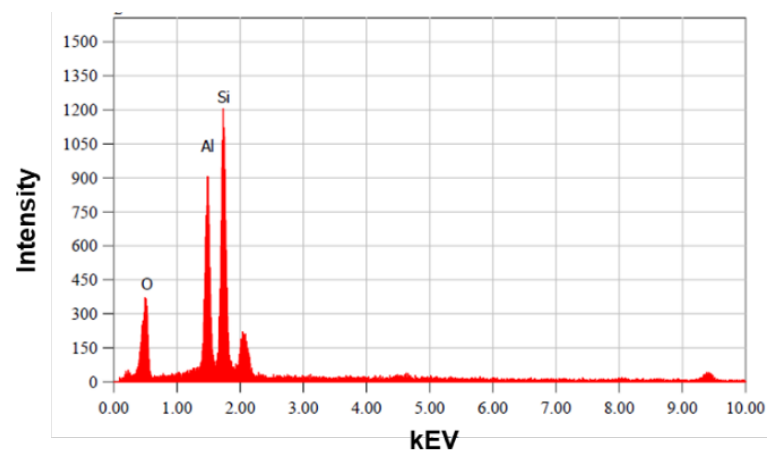

Figure 2 Composition of catalyst

The element content in the PR-02-2020 sample was dominated by La (48.5\%), Fe (14.2\%), Al (11.9\%), Ti $(11.6 \%)$ associated with minor elements such as $\mathrm{Ba}$ $(5.91 \%)$ and $\mathrm{Si}(5.6 \%)$. The content of other comorbidities is present with a proportion of $<1 \%$, such as $\mathrm{Ni}, \mathrm{Zr}, \mathrm{Ga}, \mathrm{Sr}, \mathrm{Zn}, \mathrm{Cu}$, and $\mathrm{P}$. 


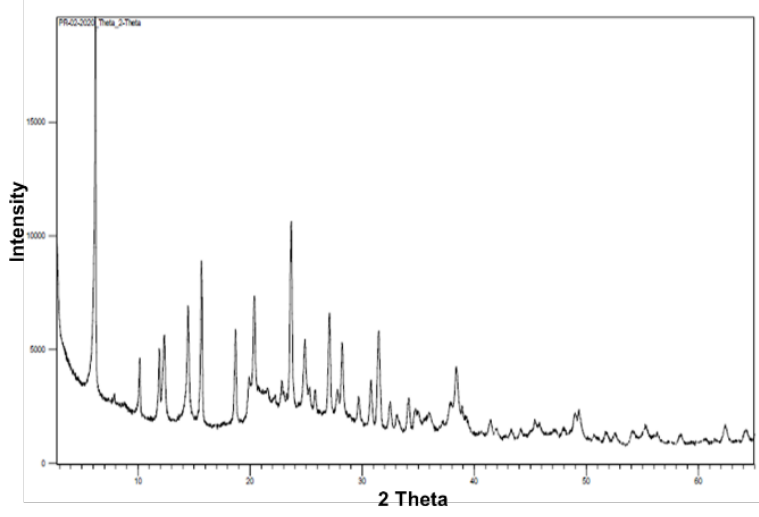

Figure 3 X-Ray Diffraction Pattern of Zeolite
XRD test results showed the dominance of zeolite content, namely Faujasite (65.00\%) and Zeolite ZSM-5 $(2 \%)$. Several other minerals that were also detected included lepidocrocite (19.00\%) and kaolinite (14.00\%). The XRD test graph on this sample can be seen in Figure 3; sample PR-02-2020.

The catalytic conversion of the PPSDM oil and gas residue into liquid fuel has been carried out using a heterogeneous acid catalyst using a bath reactor which has resulted in a convention of $40 \%$ with a temperature of $350^{\circ} \mathrm{C}$ for 60 minutes. The resulting product was analyzed using Gas Chromatography Mass Spectroscopy (GCMS) with components $\mathrm{C} 1$ to $\mathrm{C} 17$ hydrocarbon molecules (see Figure 4).

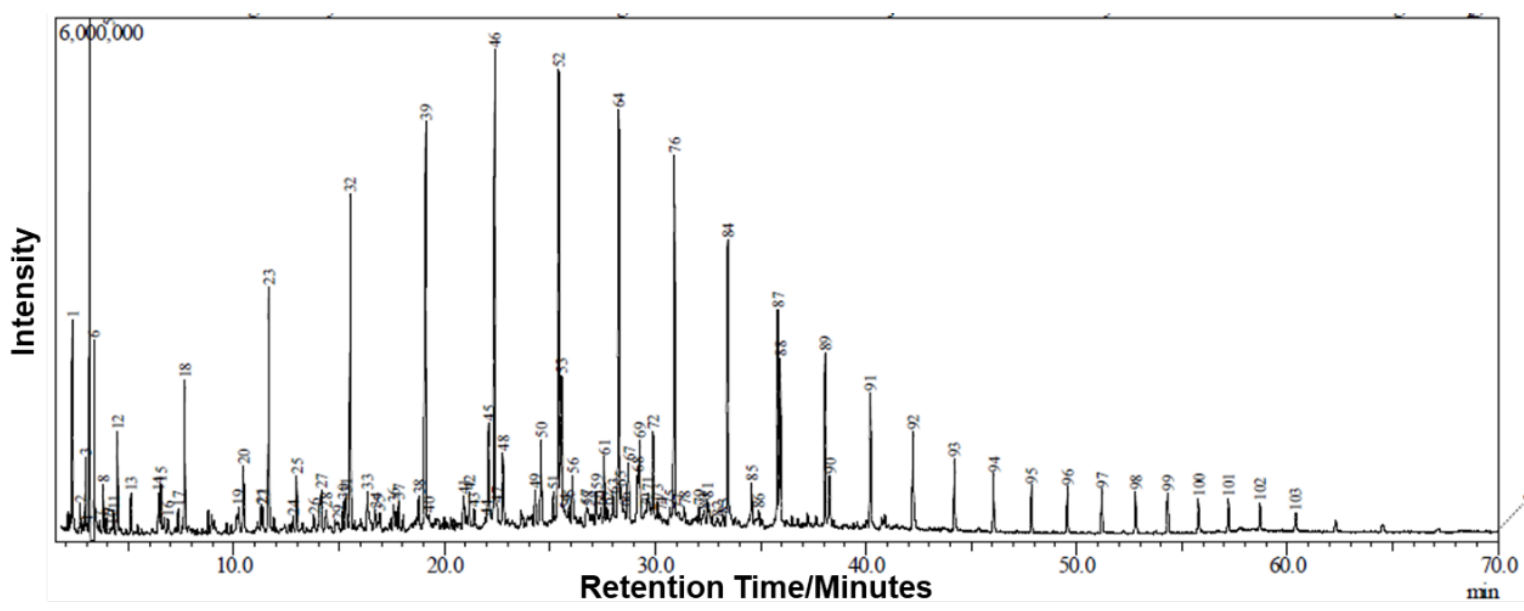

Figure 4 Spectrum Gas Chromatography Mass Spectroscopy of product catalytic cracking of residue at $350^{\circ} \mathrm{C}$ for 60 Minutes

The effect of temperature was also studied where there was an increase in the conversion of the residue with an increase in operating temperature up to $95 \%$ conversion at a temperature of $450^{\circ} \mathrm{C}$ this was due to more energy being given to the process so that large molecules could be cracked into larger hydrocarbon molecules. Where in the research will be continued by determining the optimum conditions of the process by studying the effect of pressure, the amount of catalyst and the time of the residual conversion process into light hydrocarbon fractions Figure 5.

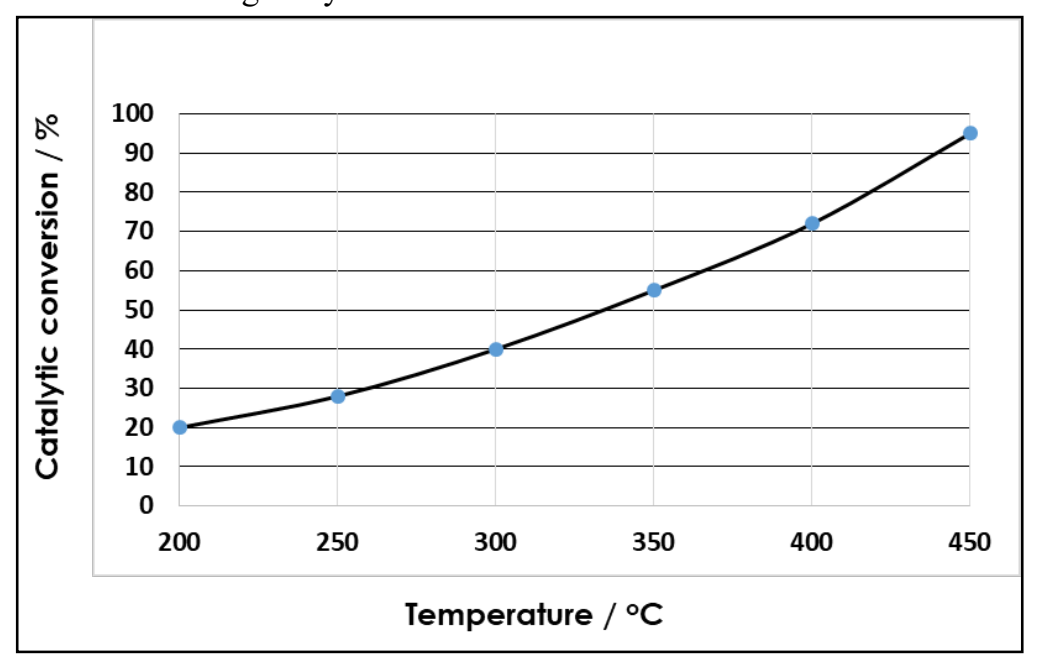

Figure 5 The Effect of temperature over catalytic conversion residue 


\section{CONCLUSION}

From the results of the research, it can be concluded that the residue from the processing of crude oil into a light fraction that a good catalyst for the conversion process of residue into liquid fuel is a heterogeneous acid catalyst with promising results because it is produced from $20 \%$ to $95 \%$ wt. with operating temperatures from 250 to $450^{\circ} \mathrm{C}$ with the product being $\mathrm{C}_{1}$ to $\mathrm{C}_{17}$ hydrocarbons molecules.

\section{ACKNOWLEDGMENTS}

A part of this work was financially supported by Politeknik Energi dan Mineral Akamigas, the Ministry of Energy and Minerals. Pusparatu is grateful to Ministry of Mine and Energy of Republik Indonesia for the grant.

\section{REFERENCES}

[1] Hartiniati, "hidrokarbon katalitik residu Minyak Bumi : Pengaruh Temperatur dan waktu reaksi, Reaktor, Vol. 10, no. 2, pp. 82-87.2006.

[2] Guoqiang Song, Wenting Chen, Peipei Dang, Shengyuan Yang, Yuan Zhang, Yuanyi Wang, Ruidi Xiao, Rong Ma and Fuxiang Li "Synthesis and Characterization of Hierarchical ZSM-5 Zeolites with Outstanding Mesoporosity and Excellent Catalytic Properties, Nanoscale Research Letters vol. 13, no, 364, 2018.

[3] Wang Y, Song J, Baxter NC, Kuo GT, Wang S, "Synthesis of hierarchical ZSM-5 zeolites by solidstate crystallization and their catalytic properties. Journal Catalysis Vol. pp. 53-65, 2017.

[4] Yin C, Feng L, Ni R, Hu L, Zhao X, and Tian D One-pot synthesis of hierarchically nanoporous ZSM-5 for catalytic cracking. Powder Technology vo. 253 , pp.10-13. 2014.

[5] Qingyan Cui, Yasong Zhou, Qiang Wei and Guanglin Yu," Performance of Zr- and P-modified USY-based catalyst in hydrocracking of vacuum gas oil, February", Fuel Processing Technology 106:439-446. 2013.

[6] Oguz Bayraktar and Edwin L.Kugler Effect of pretreatment on the performance of metalcontaminated fluid catalytic cracking (FCC) catalysts", Applied Catalysis A: General, vol. 260, no. 1 pp. 119-124, 2014.
[7] Ehsan Amini, Kamran Ahmadi, Alimorad Rashidi, Amirali Youzbashi, Mehran Rezaei, Preparation of nanozeolite-based RFCC catalysts and evaluation of their catalytic performance in RFCC process", Journal of the Taiwan Institute of Chemical Engineers, 2019.

[8] Amin Talebian-Kiakalaieh; Sara Tarighi," Synthesis of hierarchical Y and ZSM-5 zeolites using post-treatment approach to maximize catalytic cracking performance", Journal of Industrial and Engineeri ng Chemistry., 2020.

[9] E. V. Parkhomchuk; D. A. Sladkovskii; Yu. Gun; W. Wu; K. A. Sashkina; A. I. Lysikov; V. N. Parmon," Catalytic Cracking of $n$-Hexane in the Presence of Zeolite ZSM-5 Micro- and Nanocrystals", Pet. Chem., 2019.

[10] Vu XH, Bentrup U, Hunger M, Kraehnert R, Armbruster U, Martin A "Direct synthesis of nanosized-ZSM-5/SBA-15 analog composites from preformed ZSM-5 precursors for improved catalytic performance as cracking catalyst". Journal of Materials Science, vol. 49, pp. 5676-5689, 2014.

[11] He X, Ge T, Hua Z, Zhou J, Lv J, Zhou J and Liu Z, Shi J "Mesoporogen-free synthesis of hierarchically structured zeolites with variable $\mathrm{Si} / \mathrm{Al}$ ratios via a steam-assisted crystallization process. ACS Applied Materials \& Interfaces,., vol. 8, pp. 7118$712,2016$.

[12] Pedro Castaño. José María Arandes, Martin Olazar and Javier Bilbao, "Effect of hydrogen on the cracking mechanisms of cycloalkanes over zeolites" Catalysis Today, vol. 150, no. 3, pp. 363$367,2020$.

[13] Indartono, Y. (2005), "Bioetanol, Alternatif Energi terbarukan: Kajian Prestasi Mesin dan Implementasi di Lapangan", Fisika, LIPI.

[14] Farshid Mohammadparast, ouein Halladj and Sima Askari, The synthesis of nano-sized ZSM-5 zeolite by dry gel conversion method and investigating the effects of experimental parameters by Taguchi experimental design, Journal of Experimental Nanoscience Vol. 13,no. 1, 2018. 